\title{
Ethephon treatment reduced Mondo grass (Ophiopogon japonicus) gas exchange rate and gene expression of $R b c s$
}

\author{
Jun Liu ${ }^{1,2}$, Lixin $\mathrm{Xu}^{1}$, Yingbo Wang ${ }^{1}$ and Liebao $\operatorname{Han}^{1}$ \\ ${ }^{1}$ Institute of Turfgrass Science, Beijing Forestry University, Beijing, China \\ ${ }^{2}$ College of Agro-grassland Sciences, Nanjing Agricultural University, Nanjing, China
}

\begin{abstract}
Summary
Background - Mondo grass (Ophiopogonjaponicus) is a very important ornamental species and traditional Chinese herbal medicine. Genomic information of this plant is very limited. Ethephon (2-chloroethyl phosphonic acid, an ethylene-releasing compound) is a plant growth regulator with various systemic properties. The effect of ethephon on Mondo grass photosynthesis is unclear. Objectives - The study was carried out to evaluate if foliar ethephon application could promote photosynthesis rate of Mondo grass. Methods - Net photosynthesis rate $\left(\mathbf{P}_{n}\right)$ and stomatal conductance $\left(\mathrm{g}_{\mathrm{s}}\right)$ of Mondo grass was measured at various time points after ethephon treatment. In addition, a full-length enriched complementary DNA (cDNA) library from ethephon $\left(0.5 \mathrm{~g} \mathrm{~L}^{-1}\right)$ treated Mondo grass leaves was constructed to explore the underlying gene expression profile. Results - Ethephon treatment (ranging from $0.2 \mathrm{~g} \mathrm{~L}^{-1}$ to $1.5 \mathrm{~g} \mathrm{~L}^{-1}$ ) reduced Mondo grass $P_{n}$. Real time quantitative PCR results implied that ethephon inhibited Mondo grass leaf photosynthesis through down-regulating gene expression of Rubisco small subunit (Rbcs). Conclusion - Application of ethephon will not be an effective way in promoting $P_{n}$ of Mondo grass. Moreover, our data provide the first extensive set of full-length cDNA sequence resources for Mondo grass and these resources will be useful for important genes discovery, functional analysis and understanding various molecular mechanisms for Mondo grass.
\end{abstract}

Keywords

cDNA library, ethephon, net photosynthesis rate, Ophiopogon japonicus, gene expression, rubisco small subunit

\section{Introduction}

Ethephon (2-chloroethyl phosphonic acid) is a plant growth regulator (PGR) widely used on wheat, coffee, tobacco, cotton, and rice in order to help the plant's fruit reach maturity more quickly (Cutler and Cutler, 2004). It is also used in some turfgrass species to regulate growth and promote turf performances (Volterrani et al., 2015; Sidhu et al., 2014; McCullough et al., 2005). Ethephon penetrates into plant tissues and is translocated. It decomposes to ethylene which is the active metabolite (Zhang and Wen, 2010; Liu et al., 2011; Aiken et al., 2015). It is established that ethephon treatment induced disease resistance in various plants by mediating the expression of different pathogenesis-related genes such

\section{Significance of this study}

What is already known on this subject?

- As a plant growth regulator, ethephon can increase photosynthesis rate for some plant species.

What are the new findings?

- Ethephon treatment reduced photosynthesis rate of Mondo grass and the reduced gene expression of Rbcs might be one of the underlying reasons.

What is the expected impact on horticulture?

- Using ethephon might not be an effective way to promote photosynthesis rate for Mondo grass. Moreover, the constructed cDNA library can be a helpful tool to provide important nucleotide information for further studies in Mondo grass.

as in grapevine (Vitis vinifera) (Belhadj et al., 2008), mature tomato (Solanum esculentum) fruits (Wang et al., 2011) and banana (Musa acuminate) fruit (Tang et al., 2010).

The effect of ethephon treatment on plant photosynthesis is not consistent. Increase or inhibition of photosynthesis by ethephon treatment has already been reported. For instance, within 24 hours of ethephon treatment, net carbon exchange rate of the whole Xanthium strumarium plant had dropped by $35 \%$, but the inhibition by ethephon was reversed by physically repositioning the leaves with respect to the light source (Woodrow et al., 1989). In another study, photosynthesis rate of mustard was increased by ethephon treatment under high nitrogen conditions (Khan et al., 2008). The underlying mechanism of ethephon-mediated-effect on plant photosynthesis is unclear and needs further studies. However, ethylene released from ethephon or endogenous ethylene is believed to play a central role in this process. It elicits physiological responses related to photosynthesis via its effect on stomatal aperture (Khan, 2004b, a; Desikan et al., 2006) or on the influence on gene expression of rubisco and photosynthetic machinery (Iqbal et al., 2011; Tholen et al., 2007).

Mondo grass (Ophiopogon japonicus) is a perennial herb in the family of Liliaceae. It is adapted to a wide range of moisture conditions and cultivated in many areas of the world as a very important ornamental species and as traditional Chinese herbal medicine (Sendo et al., 2010; Fantz, 2009; Cao et al., 2014). Despite its importance, the genomic information of Mondo grass is very limited. In addition, more studies should be aimed to promote photosynthesis rate of Mondo grass and improve its growth. Because of the long, shiny, straight, healthy leaves, the prevailing horticul- 
tural demand of Mondo grass will increase. This study was to investigate if ethephon treatment could promote photosynthesis of Mondo grass and explore the underlying factors contributing to this process. Photosynthesis rate of Mondo grass at various time-points after ethephon treatment was investigated. Moreover, an ethephon-treated Mondo grass leaf cDNA library was constructed and photosynthesis-related gene expression was analyzed.

\section{Materials and methods}

\section{Plant material and growing condition}

Mondo grass plants were collected from Longtoushan Forestry Station in Hebei province, China $\left(42.45^{\circ} \mathrm{N} ; 117.23^{\circ} \mathrm{E}\right)$, and transferred to plastic pots $(25 \mathrm{~cm}$ in diameter, $20 \mathrm{~cm}$ in height) in a greenhouse located at the Nursery of Beijing Forestry University. The plants are vegetative materials that belong to genetically different accessions. The plastic pots were filled with soil mixture sand and soil $(1: 3 \mathrm{v} / \mathrm{v})$ and each pot was added with $10 \mathrm{~g}$ of fertilizer $\left(\mathrm{N}-\mathrm{P}_{2} \mathrm{O}_{5}-\mathrm{K}_{2} \mathrm{O}, 15-3-7\right)$. Prior to the treatment, plants were adapted and established for 2 months in the greenhouse maintained at average day/night temperatures of $23 / 16^{\circ} \mathrm{C}, 25 \pm 5 \%$ relative humidity and an average photoperiod of $11 \mathrm{~h}$ light at $450 \mu \mathrm{mol} \mathrm{m}^{-2} \mathrm{~s}^{-1}$ photosynthetically active radiation (PAR). Plants were watered every two days.

\section{Ethephon treatment and gas exchange measurement}

The experiment was a completely randomized plot design with two factors (ethephon treatment and time points after ethephon treatment). Each treatment for each time point had three replicates. The plants of Mondo grass were treated (sprayed evenly on the whole plants) at 8:00 am by different concentration of ethephon solution: $0.2 \mathrm{~g} \mathrm{~L}^{-1}$, $0.5 \mathrm{~g} \mathrm{~L}^{-1}, 1.0 \mathrm{~g} \mathrm{~L}^{-1}, 1.5 \mathrm{~g} \mathrm{~L}^{-1}$ and distilled water as control. Net photosynthesis rate $\left(\mathrm{P}_{\mathrm{n}}\right)$ at $0 \mathrm{~h}, 2 \mathrm{~h}, 4 \mathrm{~h}, 6 \mathrm{~h}$, and $8 \mathrm{~h}$ after the treatment were obtained using Portable Photosynthesis System LI-6400 (Li-6400, LICOR, Inc., Lincoln, NE) following the method described by Manter and Kerrigan (2004). The analyzer was set at $500 \mu \mathrm{mol} \mathrm{s}{ }^{-1}$ flow rate (leaf temperature of $23 \pm 0.4^{\circ} \mathrm{C}, 15 \pm 1.8 \%$ relative humidity). Our previous work indicated that the saturating light for Mondo grass is around $500 \mu \mathrm{mol} \mathrm{m} \mathrm{m}^{-2} \mathrm{~s}^{-1}$ through analyzing light response curves (Liu, 2008). Therefore, we set the light emitting diode external light source at a photosynthetic photon flux density of $500 \mu \mathrm{mol} \mathrm{m}^{-2} \mathrm{~s}^{-1}$. Net photosynthesis rate were measured on fully expanded upper most leaves on 3 plants from each replicate. Gas exchange measurements were taken after the readings had stabilized for at least $3 \mathrm{~min}$. Leaf area was evaluated according to the method by Ji et al. (2008).

\section{RNA extraction for cDNA library construction}

Total RNA was extracted following a protocol based on the CTAB (hexadecyltrimethyl ammonium bromide) method (Jaakola et al., 2001) with modifications. Briefly, $3 \mathrm{~g}$ of frozen leaf tissue were powdered under liquid $\mathrm{N}_{2}$ and were homogenized in equal volumes $(50 \mathrm{~mL})$ of $65^{\circ} \mathrm{C}$ extraction CTAB buffer containing 2\% CTAB, $100 \mathrm{mM}$ Tirs-HC1 (pH 8.0), $1.4 \mathrm{M} \mathrm{NaCl}, 20 \mathrm{mM}$ disodiumethylenediaminetetracetate (pH 8.0), 2\% $\beta$-mercaptoethanol, $2 \%$ polyvinylpyrrolidone. Following phase separation and re-extraction of the aqueous phase with an equal volume of chloroform:isoamyl alcohol $(24: 1, v / v)$, nucleic acids were precipitated by the addition of $1 / 4$ volume of $10 \mathrm{M} \mathrm{LiCl}$ at $-20^{\circ} \mathrm{C}$ for $3 \mathrm{~h}$. The precipitate was resuspended in $500 \mu \mathrm{L} 0.5 \%$ sodium dodecylsulfate and was precipitated by the addition of equal volume of chloroform:isoamyl alcohol $(24: 1, \mathrm{v} / \mathrm{v})$. The aqueous phase was extracted to a tube and added by 2 volumes of ethanol at $-20^{\circ} \mathrm{C}$ for about $2 \mathrm{~h}$. The precipitate was resuspended in sterile $500 \mu \mathrm{L} 0.01 \%(\mathrm{v} / \mathrm{v})$ diethylpyrocarbonate water with addition of $3 \mathrm{uL}$ RNase Inhibitor, $5 \mu \mathrm{L}$ DNase and $70 \mu \mathrm{L}$ $10 \times$ RNase-free Dnase Buffer. Samples were scanned with a spectrophotometer. The quality of RNA was verified by the demonstration of intact $28 \mathrm{~S}$ and 18S rRNA through agarose gel electrophoresis. Poly $(\mathrm{A}+) \mathrm{RNA}$ was isolated by PolyA Tract Systems II (Z5300) (Promega, Beijing) under standard conditions given in the manual.

\section{cDNA library construction}

A full-length cDNA enriched library was constructed from the poly (A) RNA using cDNA Library Construction Kit (TaKaRa, Beijing) according to the manufacturer's instructions. Mondo grass cDNA was ligated into the vector pAP3neo (TaKaRa, Beijing) and transformed to E. coli Electro-Cells (TaKaRa, Beijing). After incubating with shaking ( $225 \mathrm{rpm}$ ) for $1 \mathrm{~h}$ at $37^{\circ} \mathrm{C}, 1 \mathrm{~mL}$ of transformation mixture was added into the appropriate tube containing $1 \mathrm{~mL}$ of LB broth (Chung et al., 1989) and then $1 \mathrm{~mL}$ of dilution was spread onto blue-white selection media (LB-agar plates containing $100 \mu \mathrm{g} \mathrm{m}^{-1} \mathrm{am}-$

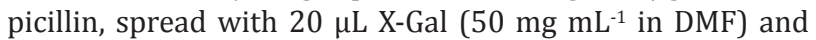
$50 \mu \mathrm{L}$ IPTG $(0.2 \mathrm{M}))$. The plates were incubated at $37^{\circ} \mathrm{C}$ overnight. White colonies were picked, grown overnight at $37^{\circ} \mathrm{C}$ in $150 \mu \mathrm{L}$ liquid LB medium containing $100 \mu \mathrm{g} \mathrm{mL}^{-1}$ ampicillin and stored with $40 \%$ glycerol stocks at $-70^{\circ} \mathrm{C}$ in sterile 96-well plates (Corning, NY).

\section{Full-length cDNA library evaluation and cDNA clone sequencing}

The average cDNA insert size and their distribution were analyzed by random sampling of cDNA clones from randomly selected plates. The sizes of $705 \mathrm{cDNA}$ clones were analyzed by PCR and agarose electrophoresis gel. The PCR primers are T3 (5'-attaaccctcactaaagggcg-3') and T7 (5'-taatacgactcactataggg-3'). Based on PCR amplification of the inserts of 705 clones, the mean and median cDNA clone length was estimated at 1,200 bp and $950 \mathrm{bp}$, respectively. The shortest cDNA clone from this subset measured $180 \mathrm{bp}$, while the longest one measured about 3,400 bp. Five hundred thirty-nine cDNA clones were randomly selected for sequencing (Sun Biotech, Beijing, http://sunbiotech.biogo.net/). Single pass sequencing was performed from both directions using two "in-house" sequencing primers. Each sequence was edited manually by removing vector sequences and the ambiguous reads. For each sampled cDNA clone, two sequence reads from both ends were aligned and were comparatively edited to generate a consensus sequence contig.

\section{Quantitative real-time PCR Analysis}

In quantitative real-time PCR analysis, total RNA from the Mondo grass leaves was isolated using RNAprep pure Plant kit (Tiangen, Beijing, China, http://www.tiangen.com/) and was treated with Rnase-Free DNase I (Tiangen, Beijing, China) to remove contaminating genomic DNA. RNA was reverse transcribed with QuantScript RT Kit (Tiangen, Beijing, China). The synthesized cDNA was subjected to PCR for 40 cycles using SuperReal PreMix (SYBR green) kit (Tiangen, Beijing, China) in a step one Real Time PCR System (Applied Biosystems, Foster City, CA, USA). The amplification of the target genes was monitored every cycle by SYBR-green fluorescence. The Ct (threshold cycle), defined as the PCR cycle 
TABLE 1. PCR primers employed in this study.

\begin{tabular}{lcc}
\hline Oligo name & \multicolumn{1}{c}{$\begin{array}{c}\text { Oligonucleotides } \\
\text { sequences } \\
\left(\text { 5' to }^{\prime}\right)\end{array}$} & $\begin{array}{c}\text { Oligo- } \\
\text { nucleotides } \\
\text { number }\end{array}$ \\
\hline CAB F & CCAAGCAATCCCTGTCCT & 18 \\
CAB R & GGGATACTTCATTCAGGC & 18 \\
Rbcs F & CATTCAACGGGCTCAAGT & 18 \\
Rbcs $R$ & TCCCTACATTTCTGTCTGC & 19 \\
Plastocyanin F & GGGAAGCCAAAGGAAAGTA & 19 \\
Plastocyanin R & TTGATCTCGCTGGGAACG & 18 \\
CS F & GCACCATGAGCGAACTA & 18 \\
CS R & GTAACAGCCTTGGCAACT & 18 \\
OEE F & TCCAGCCCACCAAACTCA & 18 \\
OEE R & CCTCTGTAACTCGGCACCAG & 20 \\
RCA F & AACGATTTCTCAACCCTGTA & 20 \\
RCA R & GACCAACCTCTTCCCAAC & 18 \\
FBA F & ATGGCTGTCTCGTTCACC & 18 \\
FBA R & GGGATACTTCATTCAGGC & 18 \\
bTubulinF & TGTGGCAACCAGATCGGTGC & 20 \\
bTubulinR & CATAAGGCCCAGTGCGGACAC & 21 \\
\hline
\end{tabular}

at which a statistically significant increase of reporter fluorescence was first detected, was used as a measure for the starting copy numbers of the target gene. Relative quantity of the target gene expression level was performed using $2^{-\Delta \Delta c(t)}$ method (Livak and Schmittgen, 2001).

Specific primers were designed according to the full length cDNA sequence of each gene (Table 1). Three biological and technical replicates were performed for each experiment.

\section{Statistical analysis}

Effects of ethephon treatment, time after treatment and corresponding interactions were determined by analysis of variance according to the general linear model procedure of SAS (Version 9.0; SAS Institute, Cary, NC). Differences between means were separated by Fisher's protected least significance difference (LSD) test at the $0.05 \mathrm{P}$ level.

\section{Results and discussion}

\section{Effects of ethephon treatment on photosynthesis of Mondo grass}

Net photosynthesis rate $\left(\mathrm{P}_{\mathrm{n}}\right)$ in Mondo grass control plants (distilled water treated) increased to $5.43 \mu \mathrm{mol} \mathrm{m}^{-2} \mathrm{~s}^{-1}$ at $4 \mathrm{~h}$ and then gradually decreased to $2.32 \mu \mathrm{mol} \mathrm{m}^{-2} \mathrm{~s}^{-1}$ at $8 \mathrm{~h}$ reflecting a basic $\mathrm{P}_{\mathrm{n}}$ diurnal change in Mondo grass (Figure 1A). The $0.2 \mathrm{~g} \mathrm{~L}^{-1}$ ethephon treatment did not affect the photosynthesis rate of Mondo grass (Figure $1 \mathrm{~A}$ ). The $1 \mathrm{~g} \mathrm{~L}^{-1}$ ethephon treatment reduced $\mathrm{P}_{\mathrm{n}}$ after 2 and $4 \mathrm{~h}$ of treatment. The $\mathrm{P}_{\mathrm{n}}$ was reduced significantly by $0.5 \mathrm{~g} \mathrm{~L}^{-1}$ at $4 \mathrm{~h}$, and by $1.5 \mathrm{~g} \mathrm{~L}^{-1}$ ethephon treatment at $4 \mathrm{~h}, 6 \mathrm{~h}$ and $8 \mathrm{~h}$. The results suggested that application of ethephon solution ranging from $0.5 \mathrm{~g} \mathrm{~L}^{-1}$ to $1.5 \mathrm{~g} \mathrm{~L}^{-1}$ had an inhibitory effect on $\mathrm{P}_{\mathrm{n}}$ in Mondo grass. Low concentration of ethephon $\left(0.2 \mathrm{~g} \mathrm{~L}^{-1}\right)$ had no effect on $\mathrm{P}_{\mathrm{n}}$. Plants maximal decrease in $\mathrm{P}_{\mathrm{n}}$ was observed in $1.5 \mathrm{~g} \mathrm{~L}^{-1}$ ethephon treated plants which implied that $1.5 \mathrm{~g} \mathrm{~L}^{-1}$ ethephon treatment had the strongest inhibitory effect on $\mathrm{P}_{\mathrm{n}}$ among all the concentration levels of ethephon used in this study.

Reduction in $\mathrm{P}_{\mathrm{n}}$ by ethephon treatment was also observed in 'Verdejo' grapevines (Vitis vinifera) (Gonzalez et al., 2011) and Wild Rhododendron delavayi Franch. (Yi et al., 2010). The reduction in $P_{n}$ was associated with decrease in chlorophyll content and stomatal conductance by ethephon treatment. Inconsistent with our results, stimulation in photosynthesis by ethephon treatment was reported in mustard cultivar (Iqbal et al., 2012b, 2011) and the increased photosynthesis was due to its effect on rubisco activity, stomatal conductance and intercellular $\mathrm{CO}_{2}$ concentration (Iqbal et al., 2012a, b, 2011; Khan, 2005). The different responses of plants to ethephon treatment might have resulted from their different sensitivity to ethylene (Arora, 2005; Aiken et al., 2015). Our results implied that ethephon-mediated-effect on photosynthesis was a plant species dependent process.

Figure 1B showed that $0.5 \mathrm{~g} \mathrm{~L}^{-1}$ and $1 \mathrm{~g} \mathrm{~L}^{-1}$ ethephon treatment reduced stomatal conductance $\left(\mathrm{g}_{\mathrm{s}}\right)$ of Mondo grass plants at $2 \mathrm{~h}$. At $4 \mathrm{~h}, \mathrm{~g}_{\mathrm{s}}$ in $1.5 \mathrm{~g} \mathrm{~L}^{-1}$ ethephon treated plants reduced significantly compared to control plants. It is worthy to note that $0.5 \mathrm{~g} \mathrm{~L}^{-1}$ ethephon treatment reduced $\mathrm{P}_{\mathrm{n}}$ but not $\mathrm{g}_{\mathrm{s}}$ (statistically not significant) at $4 \mathrm{~h}$, which indicated that stomata aperture may not be the major factor responsible for the drop in $\mathrm{P}_{\mathrm{n}}$ at this time point. Therefore, in order to explore the underlying gene expression factors that might be related to this phenomenon, plants tissue was sampled $4 \mathrm{~h}$ after $0.5 \mathrm{~g} \mathrm{~L}^{-1}$ ethephon treatment to construct a cDNA library for further analysis.

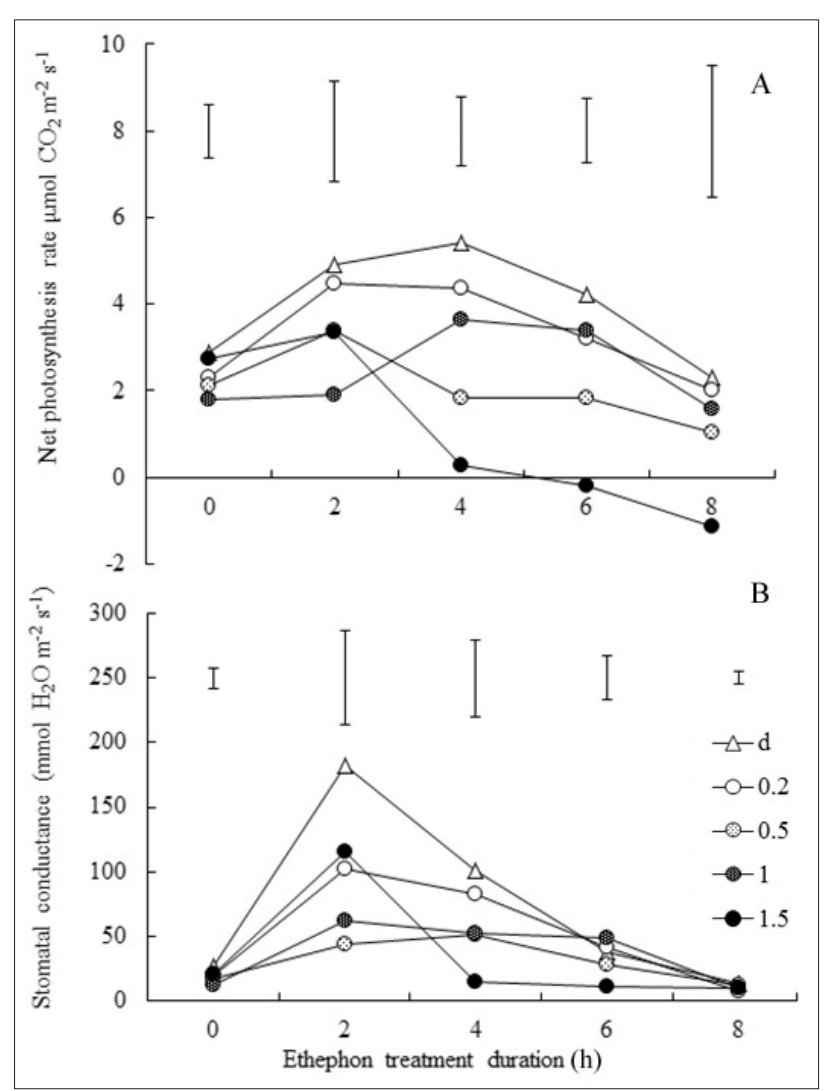

FIGURE 1. Effects of ethephon treatment on net photosynthetic rate $\left(\mathrm{P}_{\mathrm{n}}\right)(\mathrm{A})$, and stomatal conductance $\left(\mathrm{g}_{\mathrm{s}}\right)(\mathrm{B})$ in Mondo grass. Vertical bars on the top indicate LSD values $(p=0.05)$ for the comparison of 5 different concentrations of treatment at a given hour of treatment $(\mathrm{d}=$ distilled water; $0.2=0.2 \mathrm{~g} \mathrm{~L}^{-1}$ ethephon solution; $0.5=0.5 \mathrm{~g} \mathrm{~L}^{-1}$ ethephon solution; $1=1 \mathrm{~g} \mathrm{~L}^{-1}$ ethephon solution; $1.5=1.5 \mathrm{~g} \mathrm{~L}^{-1}$ ethephon solution). For each specific concentration of treatment, legends having same the letter indicate no significant difference in that particular treatment. 


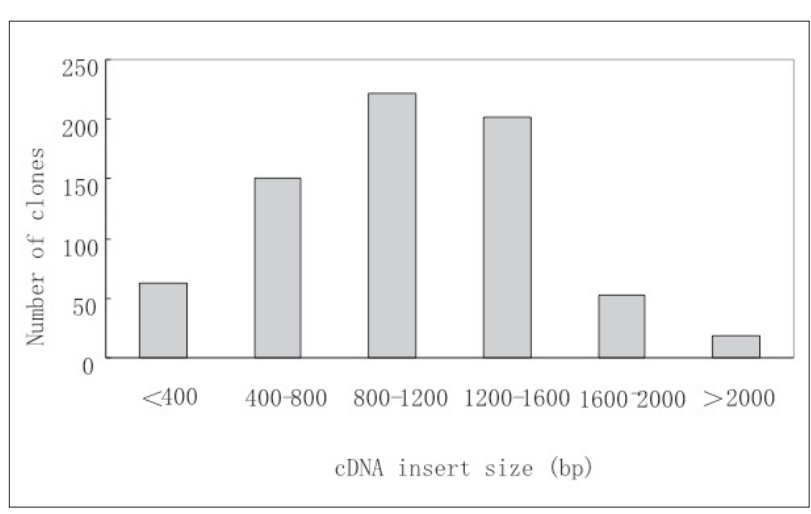

FigurE 2. The insert size distribution of full-length cDNA clones of Mondo grass leaves treated by ethephon.

\section{Characterization of the cDNA library}

The full-length enriched cDNA library consists of about 10,120 clones with an average cDNA insert of $1.2 \mathrm{~kb}$ and the rate of recombinant is above $82 \%$. Approximately, $91 \%$ of the clones had inserts longer than $400 \mathrm{bp}, 39 \%$ of the cDNA clones had inserts longer than $1.2 \mathrm{~kb}$. Only $9 \%$ of the clones had inserts smaller than 400 bp (Figure 2).

\section{cDNA sequences analysis}

For the clones longer than $400 \mathrm{bp}$, we randomly picked 534 clones to be sequenced. Sequences data of 489 clones were obtained. All edited sequence contigs were searched against the NCBI all-organism gene databases with their translated amino acid sequences. We consider that if a cDNA clone of Ophiopogon japonicus and a gene in the nr database share homology significant at an e-value of $<1.00 \mathrm{E}-5$, they likely belong to the same gene family and should share a similar broad sense function. Various lengths of open reading frames (ORFs) were identified from 489 cDNA contigs using the NCBI of finder (http://www.ncbi.nlm.nih.gov/projects/ gorf/). BLASTX evaluation of pre-determined ORF with corresponding amino acid sequences in the Gene Bank non re-

TABLE 2. Prediction annotation of cDNA clones from ethephon-treated Ophiopogon japonicus cDNA library.

\begin{tabular}{lc}
\hline Category & $\begin{array}{c}\text { Number of } \\
\text { clones }\end{array}$ \\
\hline Chloroplast/photosynthesis genes & 96 \\
Metabolism & 69 \\
Gene expression and RNA metabolism related & 67 \\
Stress/environment related & 32 \\
Ribosomal protein/ & 27 \\
protein synthesis and processing related & \\
Cell communication/signal transduction & 27 \\
Biological regulation and development & 26 \\
Ubiquitin and proteasome genes & 19 \\
Defense/senescence related & 19 \\
Transport facilitation & 14 \\
Heat-shock genes & 9 \\
Cytoskeletal/extracellular matrix & 5 \\
Cell wall and membrane related & 3 \\
Unknown/miscellaneous/others & 59 \\
Novel & 13 \\
\hline Total & 485 \\
\hline
\end{tabular}

dundant databases. Multiple ORFs with different length were frequently identified in a given cDNA sequence. The longest ORF sequence was selected from each analyzed cDNA and validated with the corresponding amino acid sequences to determine the genuine ORF. The clones fulfilling the conditions mentioned above were identified as 'full-length' if the contigs 5 ' sequence data started with methionine and a poly (A) + tail existed in the 3' sequence.

To cluster redundant clones, we compared all the sequences pairwise and grouped them on the basis of sequence similarity. Sequences were aligned using CLUSTALW, and visually inspected. We manually annotated 489 transcripts from the library into single functional classes based on GO (Gene Ontology). Individual functions were assigned on the basis of the clearest annotation of the most significant BLAST match. Where this annotation was unclear, the function of the most significant Arabidopsis match was taken into account. Transcripts are classed as 'unknown' when insufficient information was available to make a decision. In addition, 32 clones had significant homology to hypothetical proteins or unknown genes, 14 clones had some homology (e-value of $>1.00 \mathrm{E}-5$ ) or no hit to genes in the non-redundant databases which are considered as 'novel'.

From the 489 clones, we identified 291 EST sequences encoding protein products that are involved in chloroplast/ photosynthesis, gene expression and RNA metabolism related, metabolism, stress/environment related, ribosomal protein/protein synthesis and processing related, cell communication/signal transduction, biological regulation and development, ubiquitin and proteasome genes, defense/ senescence related, transport facilitation, heat-shock genes, cytoskeletal/extracellular matrix, cell wall and membrane related, unknown/miscellaneous/others, and novel (Table 2). The most abundant categories were chloroplast/photosynthesis (20\%), metabolism (14\%), gene expression and RNA metabolism related (14\%) (Figure 3). The gene bank accession numbers of the EST sequences are listed in Supplementary Table 1 .

\section{Photosynthesis related genes sampled in the library}

The most abundant genes identified in the present study are listed in Supplementary Table 2. The chlorophyll $a / b$-binding (CAB) polypeptides form supramolecular structures known as Light-Harvesting Complexes (LHCs) located in the thylakoid membrane of plant chloroplasts, where light energy is absorbed and is converted into excitation energy. They are encoded by an extended family of nuclear genes designated as Lhc genes (Schmid, 2008). In the present study, we identified three types of LHC genes namely chlorophyll $A-B$ binding protein (CAB) (putative), chlorophyll $a / b$ binding protein CP29, and type III chlorophyll $a / b$-binding protein (Supplementary Table 2). These 3 LHC genes were the most frequently observed clones in the cDNA library, followed by Rubisco small subunit (Rbcs). In addition, 2 mRNA transcripts of Rubisco activase ( $R C A)$ were identified implying an alternative splicing existence in this gene.

\section{Photosynthesis related genes regulated by ethephon}

The expression of photosynthesis related genes, $R C A$ (Rubisco activase), Rbcs (Rubisco small subunit), $C A B$ (chlorophyll $A-B$ binding protein), $C S$ (chlorophyll synthase), $F B A$ (fructose-bisphosphate aldolase), OEE (oxygen evolving enhancer) and $P C$ (plastocyanin) in ethephon-treated plants relative to control plants was analyzed at the mRNA level by quantitative PCR. Results (Figure 4) showed that ethephon 


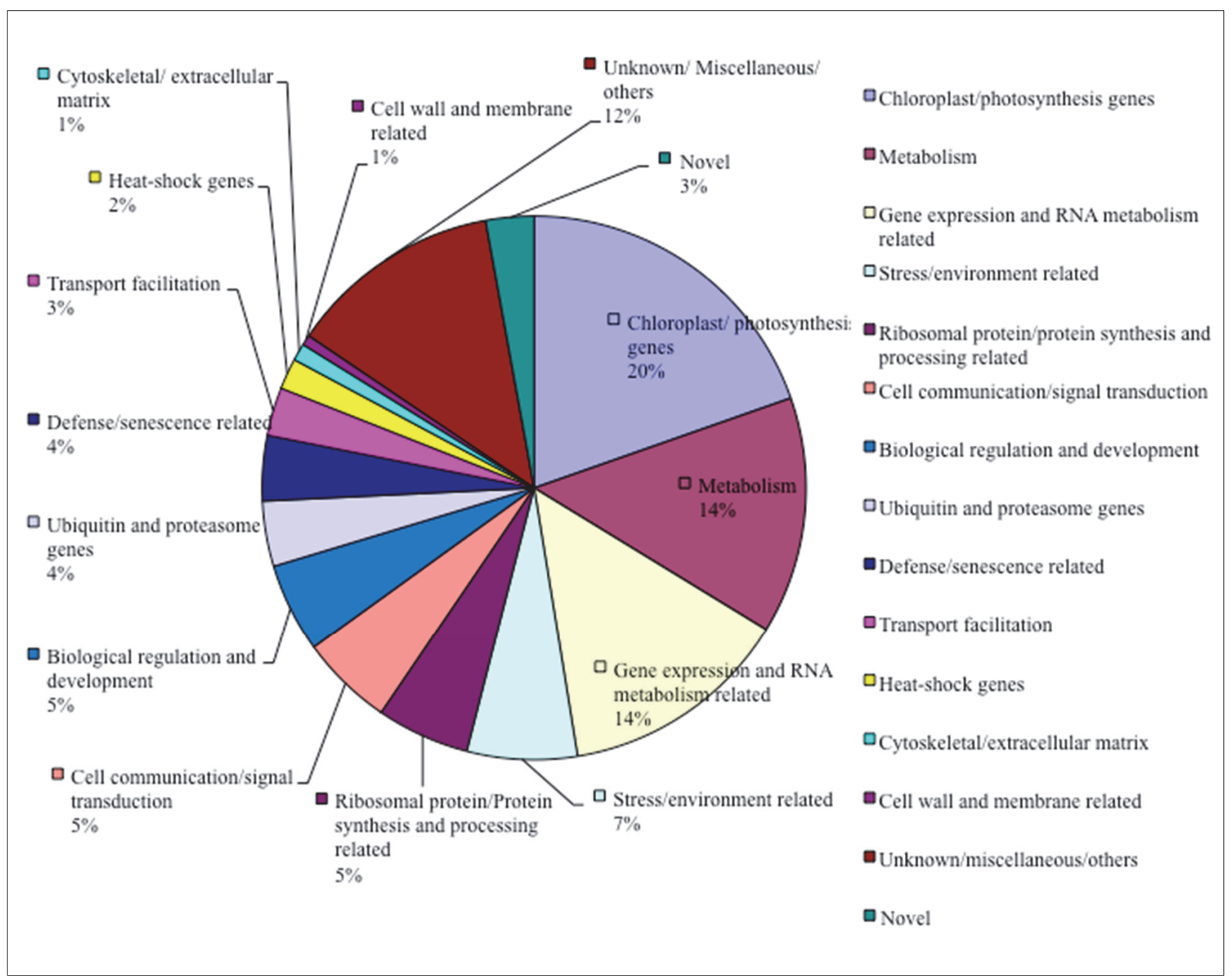

FIGURE 3. Classification of cDNA clones from ethephon treated Ophiopogon japonicus cDNA library distribution.

induced gene expression of $R C A, C A B, C S, P C$ and $F B A$ while inhibited Rbcs. Gene relative expression of $O E E$ was not affected by ethephon treatment. Down-regulation of Rbcs by ethephon might be one of the factors contributing to the reduction of net photosynthetic rate by ethephon treatment in Mondo grass.

\section{Conclusions}

The $0.5 \mathrm{~g} \mathrm{~L}^{-1}, 1 \mathrm{~g} \mathrm{~L}^{-1}$ and $1.5 \mathrm{~g} \mathrm{~L}^{-1}$ ethephon treatments reduced net photosynthesis rate of Mondo grass. The reduction in $\mathrm{P}_{\mathrm{n}}$ by $0.5 \mathrm{~g} \mathrm{~L}^{-1}$ ethephon treatment might due to down regulation of $R b c s$ by ethephon treatment. Rbcs gene expression may play a major role in photosynthesis rate limiting

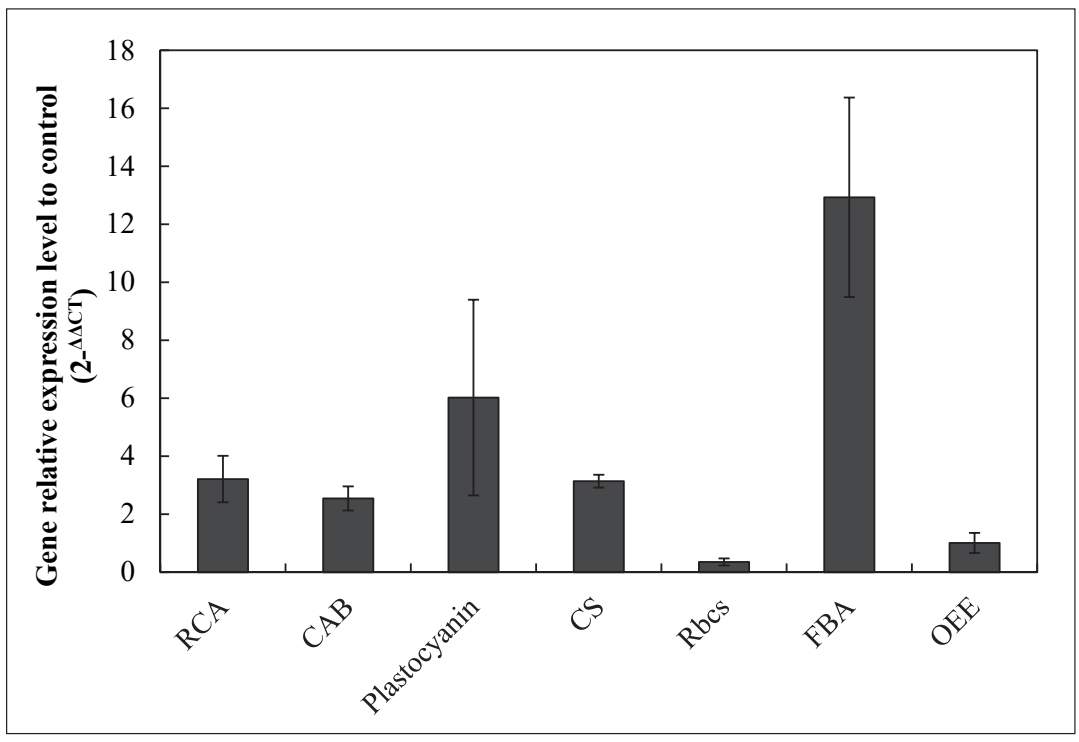

FIGURE 4. Gene relative expression of photosynthesis related genes. $R C A, \mathrm{Ru}-$ bisco activase; $C A B$, chlorophyll $A-B$ binding protein; $C S$, chlorophyll synthase; $R b c s$, Rubisco small subunit; $F B A$, fructose-bisphosphate aldolase; OEE, oxygen-evolving enhancer protein. 
process. In addition, we have developed and provided the first extensive set of full-length cDNA resources for Mondo grass. The sequencing and annotation of the ethephon treated Mondo grass cDNA library is a starting point for a holistic analysis of Mondo grass growth and photosynthesis regulation by ethephon.

\section{Acknowledgments}

This work was financially supported by the Fundamental Research Funds for the Central Universities and China SCI-TECH Association: Young Talents Development Program (2015QNRC001).

\section{References}

Aiken, M.G., Scoggins, H.L., and Latimer, J.G. (2015). Substrate pH impacts efficacy, of ethephon drenches on growth of herbaceous perennials. HortScience 50, 1187-1191. https://doi.org/10.21273/ HORTSCI.50.8.1187.

Arora, A. (2005). Ethylene receptors and molecular mechanism of ethylene sensitivity in plants. Current Sci. 89, 1348-1361.

Belhadj, A., Telef, N., Cluzet, S., Bouscaut, J., Corio-Costet, M.F., and Merillon, J.M. (2008). Ethephon elicits protection against Erysiphe necator in grapevine. J. Agric. Food Chem. 56, 5781-5787. https:// doi.org/10.1021/jf800578c.

Cao, H., Du, R., Yang, J., and Feng, Y. (2014). Study and application of methods for Ribbon's hardness evaluation of traditional Chinese medicine (TCM) produced by Roller Compaction. Latin Am. J. Pharm. 33, 499-505.

Chung, C.T., Niemela, S.L., and Miller, R.H. (1989). One-step preparation of competent Escherichia coli: transformation and storage of bacterial cells in the same solution. Proc. Nat. Acad. Sci. U. S. of Am. 86, 2172-2175. https://doi.org/10.1073/pnas.86.7.2172.

Cutler, H.G., and Cutler, S.J. (2004). Kirk-Othmer Encyclopedia of Chemical Technology: Growth Regulators, Plant (Chichester: John Wiley \& Sons, Inc.).

Desikan, R., Last, K., Harrett-Williams, R., Tagliavia, C., Harter K., Hooley, R., et al. (2006). Ethylene-induced stomatal closure in Arabidopsis occurs via AtrbohF-mediated hydrogen peroxide synthesis. Plant J. 47, 907-916. https://doi.org/10.1111/j.1365313X.2006.02842.X

Fantz, P.R. (2009). Names and species of Ophiopogon cultivated in the Southeastern United States. HortTechnol. 19, 385-394. https:// doi.org/10.21273/HORTSCI.19.2.385.

Gonzalez, R., Gonzalez, M.R., and Martin, P. (2011). Effects of ethephon on vegetative growth and fruit composition of 'Verdejo' grapevines. Agrochimica 55, 139-146.

Iqbal, N., Nazar, R., Syeed, S., Masood, A., and Khan, N.A. (2011). Exogenously-sourced ethylene increases stomatal conductance, photosynthesis, and growth under optimal and deficient nitrogen fertilization in mustard. J. Experim. Bot. 62, 4955-4963. https://doi. org/10.1093/jxb/err204.

Iqbal, N., Khan, N.A., Nazar, R., and Teixeira da Silva, J.A. (2012a). Ethylene-stimulated photosynthesis results from increased nitrogen and sulfur assimilation in mustard types that differ in photosynthetic capacity. Environm. Exper. Bot. 78, 84-90. https:// doi.org/10.1016/j.envexpbot.2011.12.025.

Iqbal, N., Nazar, R., Khan, M.I.R., and Khan, N.A. (2012b). Variation in photosynthesis and growth of mustard cultivars: Role of ethylene sensitivity. Sci. Hortic. 135, 1-6. https://doi.org/10.1016/j. scienta.2011.12.005.

Jaakola, L., Pirttila, A.M., Halonen, M., and Hohtola, A. (2001). Isolation of high quality RNA from bilberry (Vaccinium myrtillus L.) fruit. Molec. Biotechnol. 19, 201-203. https://doi.org/10.1385/ MB:19:2:201

Ji Ya-zhen. (2008). A new method for estimating the corn (Zea mays) leaf area. SCI-Tech Information Developm. \& Econ. 18, 214-215.

Khan, N.A. (2004a). Activity of 1-aminocyclopropane carboxylic acid synthase in two mustard (Brassica juncea L.) cultivars differing in photosynthetic capacity. Photosynthetica 42, 477-480. https://doi. org/10.1023/B:PHOT.0000046170.43688.8d.

Khan, N.A. (2004b). An evaluation of the effects of exogenous ethephon, an ethylene releasing compound, on photosynthesis of mustard (Brassica juncea) cultivars that differ in photosynthetic capacity. BMC Plant Biol. 4, 21. https://doi.org/10.1186/1471-2229-4-21.

Khan, N.A. (2005). The influence of exogenous ethylene on growth and photosynthesis of mustard (Brassica juncea) following defoliation. Sci. Hortic. 105, 499-505. https://doi.org/10.1016/j. scienta.2005.02.004

Khan, N.A., Mir, M.R., Nazar, R., and Singh, S. (2008). The application of ethephon (an ethylene releaser) increases growth, photosynthesis and nitrogen accumulation in mustard (Brassica juncea L.) under high nitrogen levels. Plant Biol. 10, 534-538. https://doi. $\operatorname{org} / 10.1111 /$ j.1438-8677.2008.00054.x.

Liu, J. (2008). Effect of ethylene on cloning of genes related to photosynthesis in Ophiopogon japonicus. Ph.D.-thesis, Beijing Forestry University, Beijing, China.

Liu, S.H., Zang, X.P., and Sun, G.M. (2011). Changes in endogenous hormone concentrations during inflorescence induction and development in pineapple (Ananas comosus cv. Smooth Cayenne) by ethephon. Afric. J. Biotechnol. 10, 10892-10899. https://doi. org/10.5897/AJB11.124.

Livak, K.J., and Schmittgen, T.D. (2001). Analysis of relative gene expression data using real-time quantitative PCR and the $2^{-\Delta \Delta \text { - }}$ method. Methods 25, 402-408. https://doi.org/10.1006/ meth.2001.1262.

Manter, D.K., and Kerrigan, J. (2004). A/C-i curve analysis across a range of woody plant species: influence of regression analysis parameters and mesophyll conductance. J. Experim. Bot. 55, 25812588. https://doi.org/10.1093/jxb/erh260.

McCullough, P.E., Liu, H.B., and McCarty, L.B. (2005). Response of creeping bentgrass to nitrogen and ethephon. HortScience 40, 836838.

Schmid, V.H.R. (2008). Light-harvesting complexes of vascular plants. Cell. Molec. Life Sci. 65, 3619-3639. https://doi.org/10.1007/ s00018-008-8333-6.

Sendo, T., Kanechi, M., Uno, Y., and Inagaki, N. (2010). Evaluation of growth and green coverage of ten ornamental species for planting as urban rooftop greening. J. Jap. Soc. Hortic. Sci. 79, 69-76. https://doi. org/10.2503/jjshs1.79.69.

Sidhu, S.S., Yu, J.L., and McCullough, P.E. (2014). Physiological behavior of ethephon in five turfgrasses. Crop Sci. 54, 1816-1822. https://doi.org/10.2135/cropsci2013.07.0511.

Tang, W., Zhu, S., Li, L., Liu, D., and Irving, D.E. (2010). Differential expressions of PR1 and chitinase genes in harvested bananas during ripening, and in response to ethephon, benzothiadizole and methyl jasmonate. Postharv. Biol. Technol. 57, 86-91. https://doi. org/10.1016/j.postharvbio.2010.02.007.

Tholen, D., Pons, T.L., Voesenek, L., and Poorter, H. (2007). Ethylene insensitivity results in down-regulation of rubisco expression and photosynthetic capacity in tobacco. Plant Physiol. 144, 1305-1315. https://doi.org/10.1104/pp.107.099762.

Volterrani, M., Grossi, N., Gaetani, M., Caturegli, L., Nikolopoulou, A.E., Lulli, F., et al. (2015). The effect of increasing application rates 
of nine plant growth regulators on the turf and stolon characteristics of pot-grown 'Patriot' hybrid Bermudagrass. HortTechnology 25, 397-404. https://doi.org/10.21273/HORTTECH.25.3.397.

Wang, Y.Y., Li, B.Q., Qin, G.Z., Li, L., and Tian, S.P. (2011). Defense response of tomato fruit at different maturity stages to salicylic acid and ethephon. Sci. Hortic. 129, 183-188. https://doi.org/10.1016/j. scienta.2011.03.021.

Woodrow, L., Jiao, J., Tsujita, M.J., and Grodzinski, B. (1989). Whole plant and leaf steady state gas exchange during ethylene exposure in Xanthium strumarium L. Plant Physiol. 90, 85-90. https://doi. org/10.1104/pp.90.1.85.

Yi, Y., Zhang, D., Chen, X., Xu, X., Zhang, X., Song, Q., et al. (2010). Effect of GA(3) and ethephon on photosynthesis of Wild Rhododendron delavayi Franch. HortScience 45, S251-S251.

Zhang, W., and Wen, C.K. (2010). Preparation of ethylene gas and comparison of ethylene responses induced by ethylene, ACC, and ethephon. Plant Physiol. Biochem. 48, 45-53. https://doi. org/10.1016/j.plaphy.2009.10.002.

Received: Jun. 26, 2017

Accepted: Jan. 30, 2018

Addresses of authors:

Jun Liu ${ }^{1,2}$, Lixin $\mathrm{Xu}^{1, *}$, Yingbo Wang ${ }^{1}$ and Liebao $\operatorname{Han}^{1}$

${ }^{1}$ Institute of Turfgrass Science, Beijing Forestry University,

Beijing, 100083, China

${ }^{2}$ Present address: College of Agro-grassland Sciences,

Nanjing Agricultural University, Nanjing, 210095, China

* Corresponding author; E-mail: lixinxu@bjfu.edu.cn

SUPPLEMENTARY TABLE 1. Gene bank accession number information of the EST sequences.

See this Table at: www.ishs.org/ejhs.

SUPPLEMENTARY TABLE 2. The most abundant genes in the ethephon treated Ophiopogon japonicus cDNA library.

See this Table at: www.ishs.org/ejhs. 